\title{
2
}

\section{INDIVIDUAL LIVES AND NATIONAL TRUTHS: LOCATING BIOGRAPHIES WITHIN A NATIONAL ENCYCLOPEDIA}

\author{
JOCK PHILLIPS
}

I must begin with an admission. As a historian I have long held a scepticism about the place of biography in historical studies. My sense of the role of the historian is to present the larger patterns, to paint and explain the huge social forces, the determinative cultural and political ideas, and the economic developments which forged the world of the past. Individual lives are simply the flotsam and jetsam floating above these massive historical waves. Even major political leaders or seminal thinkers need to be explained against wider social and cultural currents. In this view of the historian's mission, dictionaries of national biography become extremely useful reference works, to check the details of particular lives. They are useful for case studies, for providing the telling example. They do not contribute in themselves to the larger generalisations about nations or eras.

That is what I firmly believed until I became involved in the project to digitise the Dictionary of New Zealand Biography (DNZB). This opened up new ways of using the dictionary and its database, and created the possibility of using the individual biographies in the dictionary to inform the history of the nation itself. What had been a purely reference work, used only by historians to check biographical details, could become a tool for answering new questions central to understanding a national history. A dictionary of biography might become the biography of a nation. This discovery is the major focus of this chapter. 
Although a two-volume Dictionary of New Zealand Biography had been published in 1940 under the editorship of the journalist and librarian G. H. Scholefield, a more comprehensive and scholarly Dictionary of New Zealand Biography was begun in 1983. Under the editorship of W. H. Oliver and then Claudia Orange, the project published five volumes in English from 1990 to 2000 and five volumes of biographies of Māori subjects in the Māori language. By that stage over 3,000 lives of New Zealanders who had flourished from 1769 to 1960 had been completed. For its time this was an exciting project. The editors decided that 'representative' figures, as well as those of recognised significance, should be included. There was a sustained use of working parties to ensure that there was good representation of Māori and women, and also excellent regional representation. The standards of research and accuracy were impeccable. I was not hugely involved in the project initially. However, I did contribute eight biographies, and from 1989 when I became the nation's chief historian, with a mandate to oversee all government historical projects, I served on the project's policy committee. The project was located within the Department of Internal Affairs, and in 1997 I took over a role as general manager for a heritage group within that department. One of the first issues I faced was the projected end of the dictionary project in 2000. By that stage those people who had flourished up to 1960 would have been covered, but the principle had been established that a person had to be dead to be included in the dictionary. So it was expected that the task of writing new biographies would go into abeyance while we waited for another tranche of significant New Zealanders to die.

In common with others in the department, I decided that we should use that period to explore new uses for the outstanding biographical content. Having already established a history website (www.nzhistory.net.nz) and been astonished at its popular uptake, we decided that digitising the content of the $D N Z B$ and adding images of the subjects would add a visual richness and make the content more available to those interested in New Zealand history. We did not have any expectations beyond that. So, as a millennium project, we made the digitised material available in both English and, for all Māori subjects, in the Māori language, on a new searchable website. That act obviously made the biographies of individual lives more accessible, and the numbers using the dictionary website rose quickly. However, once the site was up and running, we began to realise that digitisation had made the content more valuable in other ways, particularly for those researching larger social forces. To take a simple 
example, if a historian were interested in the nature of temperance and prohibition, simply putting those words into the search engine of the new $D N Z B$ website produced much suggestive information about the type of people involved and why those movements arose. The word 'temperance' leads to more than 200 biographies, and 'prohibition' to more than 100 . By reading those biographies you could learn a huge amount about the nature of the temperance movement, and you could conduct a statistical analysis about the age or religious background of the prohibitionists.

\section{The Dictionary Database and the Cultural Contribution of United Kingdom- Born Immigrants}

As a result, I became interested in using the digitised $D N Z B$ content in other ways that might contribute to wider generalisations about the history of New Zealand. I made several efforts in this direction. The first came about because at that time I was deeply engaged in attempting to work out more about the geographical and social origins of the British and Irish settlers to New Zealand. In an essay in 1990 I had argued that New Zealand historical work had been singularly lacking in-depth studies of the rituals and culture (defined in its widest sense) of the society. ${ }^{1}$ If you were going to explain such matters as patterns of speech, or dress, or food, or sport, or architecture, then an essential prerequisite was to understand exactly who had settled New Zealand and what was the cultural baggage they had brought with them. The vast majority of those who had migrated to New Zealand until the 1960s came from the United Kingdom. So with Terry Hearn I sought to find out, in as much precision as possible, just who the settlers from that part of the world were from 1800 to 1945 . In the absence of census records, which had all been destroyed, the primary methodology was to carry out a one in 10 sample of the death registers of those who had been born in the United Kingdom and died in New Zealand. This would give us information about the place and county of origin of the United Kingdom migrants, their age and the date when they migrated, their religion, their family situation, and the occupation of their father.

1 Jock Phillips, 'Of Verandahs and Fish and Chips and Footie on Saturday Afternoon', New Zealand Journal of History 24, no. 2 (1990): 124. 
Our research in these sources was immensely informative, but what it lacked was a sense of the culture brought by people from particular communities, and how their geographical and occupational origins played out in the new country. Here the resources of the Dictionary of New Zealand Biography project came into their own. I realised that the individuals in the $D N Z B$ formed a relatively small proportion of the country's population and to some extent their selection had been a matter of decision-making by the editors, which might have been arbitrary. Thus simply looking at the few dictionary subjects who had been born in the Highlands of Scotland or Ulster would be a dangerous basis for larger generalisations about the nature of migrants from those areas. However, in preparing the $D N Z B$ a digital database of individuals who might find inclusion in the dictionary had been compiled by working parties throughout the country. This database was then used to select those who were given full entries. I realised that the whole database offered a more worthwhile sample than simply the Dictionary entries. True, its composition was drawn up by working parties, so it was not strictly a scientific sample, but if I was interested in significant cultural contributions then human selection was not an unhelpful bias. More importantly, the numbers were very much greater-15,000 individuals in the database as against 3,000 in the dictionary, and 3,688 born in the British Isles as against 1,082 born there in the dictionary. The database, unlike the dictionary entries, had not been systematically checked and included obvious errors and spelling mistakes, but for my purposes this was not a major issue. The great virtue of the database was that it was all available on the web (although just for internal use) and was searchable by field. It was a relatively simple exercise to search all those born in a particular place, and all those who were in a particular occupation or had a defined area of interest. The $D N Z B$ database in digital form thus opened up a much richer field of enquiry than was available through the death registers.

The first thing I noticed was that the distribution of places of origin was rather different from what we had worked out from the death registers, and indeed rather different from the census. Leaving aside Wales, which always sent very low numbers to New Zealand, and also the offshore islands, Table 1 gives the breakdown of national origins from the death registers, and Table 2 gives the percentages from the New Zealand census. ${ }^{2}$

2 Jock Phillips and Terry Hearn, Settlers: New Zealand Immigrants from England, Ireland and Scotland 1800-1945 (Auckland: Auckland University Press, 2008), 52-53. 
Table 1: National birthplaces of United Kingdom immigrants to New Zealand from Death Register sample (percentages)

\begin{tabular}{|l|r|r|r|r|r|r|}
\hline $\begin{array}{l}\text { Period of } \\
\text { migration }\end{array}$ & $\mathbf{1 8 0 0 - 3 9}$ & $\mathbf{1 8 4 0 - 5 2}$ & $\mathbf{1 8 5 3 - 7 0}$ & $\mathbf{1 8 7 1 - 9 0}$ & $\mathbf{1 8 9 1 - 1 9 1 5}$ & $\mathbf{1 9 1 6 - 4 5}$ \\
\hline England & 62.1 & 64.3 & 46.6 & 54.6 & 65.0 & 60.1 \\
\hline Scotland & 20.4 & 20.6 & 30.2 & 21.5 & 22.2 & 28.7 \\
\hline Ireland & 15.6 & 13.5 & 21.4 & 21.7 & 10.9 & 8.6 \\
\hline
\end{tabular}

Source: Death registers, Office of Births, Deaths, and Marriages.

Table 2: National birthplaces of United Kingdom-born from New Zealand Census (percentages of all United Kingdom-born people)

\begin{tabular}{|l|r|r|r|r|r|}
\hline & $\mathbf{1 8 6 1}$ & $\mathbf{1 8 7 1}$ & $\mathbf{1 8 9 1}$ & $\mathbf{1 9 1 1}$ & $\mathbf{1 9 4 5}$ \\
\hline England & 59.3 & 49.7 & 53.5 & 58.5 & 63.3 \\
\hline Scotland & 25.5 & 27.3 & 23.7 & 22.6 & 24.2 \\
\hline Ireland & 14.5 & 22.0 & 21.8 & 17.9 & 5.3 \\
\hline
\end{tabular}

Source: Census of Population and Dwellings, 1861, 1871, 1891, 1911, 1945, Statistics New Zealand. ${ }^{3}$

Both figures suggested that immigrants from England constituted about 55-60 per cent of all United Kingdom-born migrants; those from Scotland about 21-26 per cent; and those from Ireland about 15-20 per cent. By comparison, the breakdown of the $D N Z B$ database among those born in the United Kingdom was as shown in Table 3.

Table 3: National birthplaces of United Kingdom-born from $D N Z B$ database (percentages of all United Kingdom-born people)

\begin{tabular}{|l|c|}
\hline England & 66.2 \\
\hline Scotland & 21.3 \\
\hline Ireland & 10.9 \\
\hline
\end{tabular}

Source: $D N Z B$ database, Ministry for Culture and Heritage.

The exact reasons for this discrepancy need not concern us greatlyperhaps it was a reflection of the biases of the working parties, more likely it reflected the fact that the English-born were very strongly represented in the founding generations of the 1840s and established their own kith and kin in positions of eminence early. What interested me was less this discrepancy than the contrast between the representation of each country

3 See 'Census: 1871-1916', Statistics New Zealand, accessed November 2018, www.stats.govt.nz/ browse_for_stats/snapshots-of-nz/digitised-collections/census-collection.aspx. 
of birth in the database as a whole, and their representation in particular fields of achievement. For this was a way of isolating the cultural contribution of each national group to New Zealand society. When I made that comparison, certain revealing trends became evident. In the database, as we have seen, those born in England were 66.2 per cent and about 60 per cent in the death registers. But among those who were included in the database because they had made a mark in public administration (that is, as politicians or civil servants) the English constituted 77.2 per cent of the United Kingdom-born among that group. In other words, they were strongly overrepresented. Less striking, but also of significance, was that among those noted for sporting accomplishment: 68.2 per cent of the United Kingdom-born were of English birth. It may not come as a surprise to discover that English migrants achieved in these two fields. The early arrival of the English and their contacts with imperial officials meant they established the main political institutions, and the preferred sporting games (golf being a striking exception) were mainly introduced by old boys of English public schools. Nevertheless, the exercise had given us good statistical evidence for the cultural contribution of the English.

Turning to the Scots, again suggestive patterns were revealed. As noted, 21.3 per cent of the United Kingdom-born in the database were born in Scotland, but among those distinguished for their role in education the figure was 23.4 per cent, while among the scientists it was 24.0 per cent, and among those noted for their contribution to the health occupations 26.8 per cent came from Scotland. The famed role of Lowland Scots in higher education and science was confirmed. ${ }^{4}$ It helped explain why the New Zealand educational system took its model from Scotland. The most striking finding related to the Irish-born. While only 10.9 per cent of the United Kingdom-born people in the database were born in Ireland, the proportion of those who were noted for their role in the police and were born in Ireland was just over 40 per cent. Also of considerable interest was the fact that of those in the database who were distinguished for their activity in social reform movements, 57 per cent were from the Methodist, Presbyterian, or Baptist faiths, which was a significant overrepresentation. This was strong confirmation of the distinctive impact

4 Tom Brooking, 'Sharing Out the Haggis: The Special Scottish Contribution to New Zealand History', in The Heather and the Fern: Scottish Migration and New Zealand Settlement, eds Tom Brooking and Jennie Coleman (Dunedin: Otago University Press, 2003), 54; Brad Patterson, Tom Brooking, and Jim McAloon, Unpacking the Kists: The Scots in New Zealand (Dunedin: Otago University Press, 2013). 
of those religious groups, particularly in such movements as temperance. ${ }^{5}$ None of these findings about the cultural contributions of particular national and religious groups will surprise greatly. They accord with wellknown assumptions, but the dictionary database did provide a more secure basis for claims of cultural influence than simply impressionistic claims or anecdotal references. In this way, a dictionary of national biography went beyond the study of individuals and became a tool for wider truths about the nation's cultural history.

\section{The Integration of the Dictionary of New Zealand Biography and Te Ara-The Encyclopedia of New Zealand}

My second example concerns the attempt to integrate the Dictionary of New Zealand Biography into a national encyclopedia. The idea for a new national encyclopedia on the web grew out of the $D N Z B$ project. By the late 1990s, work on the five volumes of the dictionary was winding down, because, as we have noted, there were not enough people from the $1970 \mathrm{~s}$ and 1980s who had yet died and who might fill a next volume. We would have to wait perhaps 15 years. Further, another major national project prepared by the Historical Branch of the Department of Internal Affairs, the New Zealand Historical Atlas, had just been published. ${ }^{6}$ So there were the scholarly resources and experienced people available to undertake another reference work.

A previous official national encyclopedia had been published in 1966 under the editorship of A. H. McLintock. ${ }^{7}$ Thirty-one thousand copies of the three-volume set had been published. The whole print run was sold within three months and it was never reprinted. Since 1966 there had been major new developments in scholarship about the country. Increasingly, people came to me as the nation's chief historian_-publishers, scholars, and staff at the $D N Z B$ - urging the Department of Internal Affairs to embark on a new encyclopedia. I was a bit reluctant, believing that primary research, rather than superficial summaries of established knowledge, was where

5 See John Stenhouse, 'God's Own Silence: Secular Nationalism, Christianity and the Writing of New Zealand History', New Zealand Journal of History 38, no. 1 (2004): 52-71; Phillips and Hearn, Settlers, 182-87.

6 Malcolm McKinnon, ed., Bateman New Zealand Historical Atlas (Auckland: Bateman, 1997).

7 A. H. McLintock, ed., An Encyclopaedia of New Zealand (Wellington: Government Printer, 1966). 
the energy should go, but in 1998 I agreed to put in a budget bid to the government for a new official print-based encyclopedia to be produced by the department. The bid was turned down.

The next year we started the process of digitising the $D N Z B$ and also continued to develop the New Zealand history website. We had established the latter in 1997 originally as a shop window for our own historical publications, but increasingly it morphed into a general site about New Zealand history. We were stunned by the responses to these ventures. Very quickly nzhistory.net.nz was attracting over 50,000 visitors a month, and when the $D N Z B$ appeared on the web, users quickly discovered how accessible and useful it was in this form. We became convinced that the web was made for reference works, and offered exciting advantages over a print version in terms of searchability, accessibility, and the opportunity to add multimedia resources. So we prepared a new budget bid, this time for an encyclopedia of New Zealand on the web, which would be prepared in themes and published, one theme a year, over nine years. I mocked up a sample entry, gave a half-hour presentation to the minister of finance (a former historian, Michael Cullen), and briefed the prime minister, Helen Clark, who fortunately was also the minister for arts, culture, and heritage. We got the money. ${ }^{8}$

The question then arose as to the relationship between the $D N Z B$ and the new digital encyclopedia, which we soon christened-with the help of our Māori advisory committee_-Te Ara (the pathway). Traditionally, encyclopedias have included biographies of people who are considered significant to the nation's story. The 1966 encyclopedia had contained over 550 such biographies. But there seemed little point in copying the McLintock model and commissioning new biographies, for highquality biographies had just been completed for the $D N Z B$. Since they were already in digital form, the obvious solution was to integrate those biographies into Te Ara. I was keen that this would not simply be a marriage of convenience. My hope was that in bringing the biographies into the encyclopedia, they could be given a wider context, and the individual lives could contribute to understanding national (and international) social and cultural processes.

8 On the origins of Te Ara, see 'Te Ara-A History', Te Ara-The Encyclopedia of New Zealand, accessed 30 June 2017, www.TeAra.govt.nz/en/te-ara-a-history. 
The first theme of Te Ara concerned the peoples of New Zealandabout half the entries on the iwi or tribes of the country, and half on the settlement or immigrant groups. ${ }^{9}$ As we prepared it, we decided to link relevant biographies closely to the encyclopedia content. Each Te Ara entry was broken down into what we called subentries of 400 to 700 words in length. This was partly to make the presentation work better on the web. The entries varied in length from that on the English which had 14 subentries, and that about Ngāi Tahu which had 10, to those on the Tokelauans and the Rangitāne tribe which each had four. We decided that each subentry would be linked to up to six $D N Z B$ biographies, of individuals who came from that community and were pertinent to the theme of that page. Initially, we introduced each biography with a short summarising blurb that spelled out the relevance of the person's life to the theme of that subentry. For example, in the page in the English entry about that group's contribution to sport and popular culture, we find biographies of Kathleen Nunneley, a pioneering tennis player; Henry Redwood, a racehorse breeder known as 'Father of the New Zealand turf'; and Joel Polack, who among other things established the country's first brewery. ${ }^{10}$ After the first theme, however, we decided that this exercise of writing explanatory blurbs was just too demanding of our writers' time. Instead we simply linked the biographies to the subentry.

This was still a significant contribution. On the basis of oral comments and notes to the Te Ara team, we realised that users did find the linked biographies significantly added to the experience of using Te Ara. Hyperlinking biographies gave a human richness and a telling detail to stories which necessarily were highly generalised. Let us take another example. In the entry about mountaineering in New Zealand there is a subentry entitled 'Beginnings'. It tells us, among other things, that:

In defiance of Māori tapu, Taranaki was climbed in 1839 by the whaler James Heberley and scientist Ernst Dieffenbach ... Subsequently, climbers were active on North Island mountains mainly for recreation and instruction. There are difficult winter ice-climbing routes on Taranaki and Ruapehu. Taranaki has claimed many lives, and on 26 July 1953 six died on its slopes. ${ }^{11}$

\footnotetext{
9 'Māori New Zealanders', Te Ara-The Encyclopedia of New Zealand, accessed 30 June 2017, www.teara.govt.nz/en/maori-new-zealanders; 'New Zealand Peoples', Te Ara-The Encyclopedia of New Zealand, accessed 30 June 2017, www.teara.govt.nz/en/new-zealand-peoples.

10 Terry Hearn, 'English-Popular Culture', Te Ara-The Encyclopedia of New Zealand, updated 13 July 2012, accessed 30 June 2017, www.TeAra.govt.nz/en/english/page-12.

11 John Wilson, 'Mountaineering-Beginnings', Te Ara-The Encyclopedia of New Zealand, accessed 30 June 2017, www.TeAra.govt.nz/en/mountaineering/page-2.
} 
That is all we learn about climbing on Taranaki, or Mt Egmont as it has also been known. But among the linked biographies we find Harry Peters, a German immigrant who bought a farm on the slopes of Mt Egmont. The biography tells us that Peters had made his first ascent of Mt Egmont in 1885 using a new route, and six years later he had a military barracks moved from Marsland Hill, the site of the British camp in the New Zealand Wars, and placed on North Egmont at the start of the new route. Peters became the custodian and official guide and led almost 90 expeditions up the mountain including a famous 18-hour ascent by the 78-year-old ex-premier Sir William Fox. ${ }^{12}$ The biographical link provides a humanity and fascinating level of detail, which the simple encyclopedia entry cannot achieve.

So the $D N Z B$ enriches the national story and contributes to an understanding beyond the interest of an individual life. But what about the reverse process? If the $D N Z B$ entries can give detail to the encyclopedia's broad topics, those broad topics could also inform and give context to the individual life. Let us stay with the same subentry, 'Beginnings' in the 'Mountaineering' story, and, since 2016 was the centenary of his death, let us start exploring (a well-chosen word in the circumstance) the life of Charlie Douglas. On this subentry there is a link to his biography and also a picture of Douglas with his climbing mate, A. P. Harper. If we go to his biography we learn that, as his nickname 'Mr Explorer Douglas' suggests, Douglas was of some significance as an explorer of the valleys of the West Coast of the South Island. It was an area of huge rainfall, where Douglas believed the barometer 'did not appear to have much effect on the weather'. Rivers ran dangerously high, but Douglas learned that 'not being able to swim had saved his life many a time'. ${ }^{13}$

The biography gives us nice quotes and personal details about an eccentric man. But what was his larger significance? The biography certainly ends with the claim that he was 'one of New Zealand's greatest explorers'. ${ }^{14}$ To get a larger perspective, however, we can go to the Te Ara entries where he is mentioned. The obvious place to start is the entry on 'European

12 Ron Lambert, 'Peters, Harry', Dictionary of New Zealand Biography, first published 1993. Te Arathe Encyclopedia of New Zealand, accessed 30 June 2017, www.TeAra.govt.nz/en/biographies/2p12/ peters-harry.

13 Graham Langton, 'Douglas, Charles Edward', Dictionary of New Zealand Biography, first published in 1993, updated November 2007. Te Ara-The Encyclopedia of New Zealand, accessed 30 June 2017, www.TeAra.govt.nz/en/biographies/2d16/douglas-charles-edward.

14 Langton, 'Douglas, Charles Edward'. 
Exploration'. There are nine subentries in that story. The last one is entitled 'The End of Exploration' and two-thirds of the page is devoted to Douglas, giving some sense of his importance. The page begins:
By the mid-1860s, Europeans had penetrated all of New Zealand's habitable land. All that remained were the least accessible valleys and mountains of the Southern Alps ... More than anyone else, Charlie Douglas, one of the real characters in New Zealand exploration, was responsible for putting alpine South Westland onto the country's maps. ${ }^{15}$

The page also confirms his stature as an explorer by noting that he was awarded the Gill Memorial Prize by the Royal Geographical Society for his persistent explorations of Westland. On the same page, there are two revealing images. The first is his sketch of Baker's Saddle, which tells us that Douglas was of some importance as an artist, and next is a map he made of the Haast River area, where we learn that Douglas was also an outstanding map-maker whose collection of maps, one of which was five metres wide, were displayed at the International Exhibition at Christchurch in 1906 and 1907. So he is important as a cartographer. This page gives us a wider context, but it also fills out some interesting details. We find out, for example, that he had a skill in bestowing names: 'Charlie Douglas liked classical names for mountains, such as Castor and Pollux. He also coined names for creeks on the west side of the Waiatoto: Lucky Rill, Tingling Brook, Ferny Rivulet, Whizzing Water, Thrill Creek and Madcap Torrent'. ${ }^{16}$

Where else do we find Charlie Douglas in Te Ara? We get taken to the entry on 'Birdwatching', where in the page on 'New Zealand's Bird-Watching History' we discover that his diaries contained important descriptions of bird behaviour including ways to catch and cook different species. ${ }^{17}$ This is confirmed by the section on kākāpō in the entry on 'Large Forest Birds', where Douglas's observations are the main source of evidence for their decline in the nineteenth century. We learn that:

15 Jock Phillips, 'European Exploration-The End of Exploration', Te Ara-The Encyclopedia of New Zealand, accessed 30 June 2017, www.TeAra.govt.nz/en/european-exploration/page-9.

16 Phillips, 'European Exploration-The End of Exploration'.

17 Gordon Ell, 'Birdwatching-New Zealand's Birdwatching History', Te Ara-The Encyclopedia of New Zealand, accessed 30 June 2017, www.TeAra.govt.nz/en/birdwatching/page-6. 
In 1899, the explorer Charlie Douglas forecast that the kākāpō was 'doomed to extinction long before the Kiwi and the Roa [great spotted kiwi] are a thing of the past'. Partial to boiled kākāpō himself, Douglas noted that 'they could be caught in the moonlight, when on the low scrub, by simply shaking the tree or bush till they tumbled on the ground, something like shaking down apples. ${ }^{18}$

Similarly, using the search engine to search for Charlie Douglas takes us to the entry on 'Kiwi', which tells us that Douglas was one of the few Europeans to eat kiwi: 'He thought the eggs made great fritters when fried in oil from the kākāpō bird, but was less sure about the meat ... He said the best description of the taste was "a piece of pork boiled in an old coffin"'. ${ }^{19} \mathrm{He}$ appears in the story about 'Freshwater Fish', where his observations of the giant kōkopu or cock-a-bulla are noted, ${ }^{20}$ and in the one on 'Glaciers', where his explorations and pioneering survey of the Fox Glacier are highlighted for allowing the documentation of changes to the glacier. $^{21}$

Finally, there are two other intriguing mentions of Douglas. In the story about 'Scots', he is listed among a group of others of that origin who made contributions to exploring and natural history; ${ }^{22}$ in the story about 'Pets', he is cited as the best example of the dependence of people on animals in extreme situations: 'From the late 1860s Charlie Douglas spent nearly 20 years exploring and mapping South Westland with only a dog for company (all his dogs were called Betsey Jane)'. ${ }^{23}$ In sum, by exploring $T e$ Ara alongside his biography, we can both position Charlie Douglas in his larger significance in New Zealand history, and also gain intriguing details about this unusual man. Moving both ways, from Te Ara subentries to biographies, and from biographies to entries, is informative, enriching

18 Gerard Hutching, 'Large Forest Birds-Kākāpō', Te Ara-The Encyclopedia of New Zealand, accessed 30 June 2017, www.TeAra.govt.nz/en/large-forest-birds/page-5.

19 Jock Phillips, 'Kiwi-Kiwi and People: Early History', Te Ara—The Encyclopedia of New Zealand, accessed 30 June 2017, www.TeAra.govt.nz/en/kiwi/page-4.

20 Bob McDowall, 'Freshwater Fish-More Galaxiids', Te Ara-The Encyclopedia of New Zealand, accessed 30 June 2017, www.TeAra.govt.nz/en/freshwater-fish/page-4.

21 Eileen McSaveney, 'Glaciers and Glaciation-Glaciers and People', Te Ara-The Encyclopedia of New Zealand, accessed 30 June 2017, www.TeAra.govt.nz/en/zoomify/10751/map-of-the-franzjosef-glacier.

22 John Wilson, 'Scots-Education', Te Ara-The Encyclopedia of New Zealand, accessed 30 June 2017, www.TeAra.govt.nz/en/scots/page-9.

23 Nancy Swarbrick, 'Pets-History of Pets in New Zealand', Te Ara-The Encyclopedia of New Zealand, accessed 30 June 2017, www.TeAra.govt.nz/en/pets/page-2. 
understanding and context. Sadly, while I was able to establish links between the Te Ara entries and the DNZB, the reverse process-from biographies to Te Ara context-was never automated and the user has to draw on the search engine in order to accomplish it.

\section{A New Home Page and New Biographies}

There were several other ways in which we did succeed in giving the biographies a larger place in the national story while integrating the $D N Z B$ with Te Ara. One was to introduce a new home page for the biographies. ${ }^{24}$ Here we provided two suggestive groupings. We provided a facility whereby the user could group people by occupation-carvers, criminals, inventors, nurses, and so on. The idea was to encourage users to make broader generalisations and to offer a quick entry point for people thinking about those pursuits in general. The other device was to pull together themes within photographs and paintings. One of the steps forward in digitising the $D N Z B$ was that it allowed us to add portraits. So this device takes elements from within those portraits and pulls them together. The theme might be musical instruments, or beards, or moko (Māori face tattoos), or hats. Contrast and comparison is encouraged.

The second development was to begin planning new biographies for people who had died since the last volume of the $D N Z B$ was completed in 2000. It was clearly unacceptable to have a national encyclopedia that failed to include a decent entry on such a national hero as the mountaineer Sir Edmund Hillary. But Hillary had died after the last volume was completed. We decided to add 15 new biographies of the most significant people who had died since then. They included, besides Hillary, politicians like Sir Robert Muldoon and David Lange; creative artists like Hone Tuwhare, Allen Curnow, Barry Crump, Janet Frame, and Douglas Lilburn; and sportspeople like the great athletics coach Arthur Lydiard. Here we took the opportunity to make reading the biographies more user-friendly by adding to their presentation the tricks we had developed for Te Ara-dividing the whole biography into shorter subentries; adding headings within the text; and greatly enriching the story with more illustrative resources, such as photographs, paintings,

24 'Biographies', Te Ara-The Encyclopedia of New Zealand, accessed 30 June 2017, www.teara.govt. nz/en/biographies. 
and cartoons, but also interactive maps and videos. These again served to widen the appeal of the entries beyond the simple factual biography. In Hillary's biography, you will find a map showing the stages of the climb up Everest in 1953; ${ }^{25}$ in Curnow's you will find two telling excerpts from a film about him, Early Days Yet, while in the additional sources on Curnow there is a link to the full film on the moving image website, NZonscreen (www.nzonscreen.com). ${ }^{26}$ The focus remains biographical, but the richness of the visual and sound resources certainly broadens the understanding of the individual's life.

\section{The Making of Modern New Zealand- A Proposal}

As we developed these 15 new biographies, and then as the initial Te Ara build came to an end, we began to realise that so much time had elapsed there was now a sufficient number of significant people who had flourished in the period since the 1950s and had then died that a new tranche of biographies was called for. However, I was not persuaded that simply bidding for a revival of the old $D N Z B$ would have much political appeal. Furthermore, I was even more strongly convinced from our experience that pulling together individual biographies with contextual material on a digital platform was an exciting way to go. The biographies needed to work as a contribution to the general history of the nation.

Therefore, we developed a proposal entitled 'The Making of Modern New Zealand'. We would prepare interpretive essays about the history of New Zealand since 1960, with an underlying argument that New Zealand had undergone a massive change in culture and identity over those years. We would explore this change in various areas, such as high culture, popular culture, ethnicity and immigration, the place of Māori in society, gender roles, attitudes towards the environment, sport, religion, foreign policy, the rise of the city, industrial development, and farming. The high-level topics already covered in Te Ara would provide a good starting

25 Shaun Barnett, 'Hillary, Edmund Percival', Dictionary of New Zealand Biography, first published in 2010. Te Ara-The Encyclopedia of New Zealand, accessed 30 June 2017, www.teara.govt.nz/en/ interactive/28428/final-ascent-of-everest.

26 Terry Sturm, 'Curnow, Thomas Allen Monro', Dictionary of New Zealand Biography, first published in 2010. Te Ara-The Encyclopedia of New Zealand, accessed 30 June 2017, www.teara. govt.nz/en/biographies/6c1/curnow-thomas-allen-monro/sources. 
point. Alongside this exercise, we would research and write biographies of significant people who had flourished since 1960. The idea was that the specialists whom we contracted to prepare the general essays would also suggest new relevant biographies. The interpretive essays would have rich linking to the new biographies, and in turn the biographies would be written with the contextual essays in mind. Thus the user would be led almost seamlessly from an essay about, for example, the transformation of New Zealand film-making, to essays about the prominent directors and producers and actors who made it happen. And if you started with an interest in a particular film-maker, you would be encouraged to explore the contextual essays. Obviously this would have been a challenging exercise, and there might have been a danger that significant people who did not fit easily into one sphere of significant activity and change might fall by the wayside. But I find it hard to think of such a person, and in any case a contribution to an important area of New Zealand life would seem like a good place to begin choosing dictionary of national biography subjects.

The idea received quite a warm reception. Many people recognised that the past half-century had indeed seen a revolution of national identity following Britain's entry into the European Economic Community, the rise of a baby boomer generation with new ideas and politics, and the massive movement of Màori into the city and a greater number of nonBritish immigrants into the nation as a whole. New Zealand became a diverse, urban, and cosmopolitan society. But there had been little real research on this transformation. People could see the intellectual need, and there was a warm response to the idea of doing general work alongside individual biographies. The idea, however, never came to fruition, largely because of fiscal stringency, and a government department which had looked with envious eyes on the funding dedicated to Te Ara as a route out of its own insolvency. Not only did this project never get funded, but the staff and funding dedicated to Te Ara disappeared and we had the absurd situation of a major dictionary of biography and a national encyclopedia available on the web, but few resources or person power to keep them up to date. Finally, in 2017, it was announced that there would be 15 new biographies a year added to the Dictionary of New Zealand Biography. This was a welcome step forward. What remains disappointing is that the attempt to link biography and national context in the preparation of a significant national reference work never got off the ground. 
When major reference works such as a dictionary of national biography or a national encyclopedia are funded through the taxpayers of the nation, it is hard to avoid the whims of our political masters. We should be grateful that at least for almost 30 years, from 1984 to 2014, the New Zealand Government gave us the money to produce the DNZB and Te Ara. What we must now hope is that the resumption of work on the dictionary also triggers a new look at ways of linking that reference work with Te Ara. The intellectual possibilities of such a linkage are too good an opportunity to leave undeveloped. 
This text is taken from 'True Biographies of Nations?': The Cultural Journeys of Dictionaries of National Biography, edited by Karen Fox, published 2019 by ANU Press, The Australian National University, Canberra, Australia.

doi.org/10.22459/TBN.2019.02 